\title{
Strategic Approaches to Sustainable Urban Renewal in Developing Countries: A Case Study of Shenzhen, China
}

\author{
Zhiyong Yi ${ }^{1,2}$, Guiwen Liu ${ }^{1, *}$, Wei Lang ${ }^{3, *}{ }^{(\mathbb{D}}$, Asheem Shrestha ${ }^{4}$ and Igor Martek ${ }^{4}$ \\ 1 School of Construction Management and Real Estate, Chongqing University, Chongqing 400045, China; \\ yizhiyong@cqu.edu.cn \\ 2 Department of Building and Real Estate, The Hong Kong Polytechnic University, Hung Hom, Kowloon, \\ Hong Kong, China \\ 3 Department of Urban and Regional Planning, Sun Yat-sen University, Guangzhou 510275, China \\ 4 School of Architecture and Built Environment, Deakin University, Geelong 3220, Australia; \\ asheem.shrestha@deakin.edu.au (A.S.); igor.martek@deakin.edu.au (I.M.) \\ * Correspondence: gwliu@cqu.edu.cn (G.L.); langw3@mail.sysu.edu.cn (W.L.); \\ Tel.: +86-23-65120976 (G.L.); +86-20-84112583 (W.L.)
}

Received: 15 July 2017; Accepted: 15 August 2017; Published: 17 August 2017

\begin{abstract}
Successful urban renewal requires a multifaceted strategic approach incorporating both local and regional regulations, developed through multi-sector and multi-agency partnerships. In practice, developments in China unfold as discrete projects without a broader consideration for city planning or long-term sustainability. Critically, no strategic manifesto has yet emerged to direct sustainable urban renewal (SUR) as a whole in Chinese cities. To improve understanding of existing practices and their applicability to current issues facing urban renewal programs, this study performs a SWOT (strengths, weaknesses, opportunities, and threats) analysis of urban renewal within Shenzhen City, China. Data identifying specific strategies are collected from a literature review, relevant urban renewal regulations, government documents, interviews with experts and focus group meetings. Findings identify six potential strategies able to uphold SUR development in Shenzhen, with further transferability to other Chinese cities.
\end{abstract}

Keywords: sustainable urban renewal (SUR); SWOT analysis; developing country; Shenzhen; China

\section{Introduction}

Urban renewal has emerged in developing countries as a response to shifting expectations that abandoned and derelict urban buildings be refurbished and reused, rather than demolished [1]. In the context of Shenzhen, urban renewal refers to the comprehensive improvement, functional renovations or demolition and reconstruction works, which are carried out in urban built-up areas under the regulation of urban planning authorities (including old industrial, commercial and residential areas, villages within the city, and old tract houses, etc.) [2]. The term 'sustainable development' refers to the idea of merging sustainability concepts to secure long-term economic, environmental and social well-being within urban renewal development $[3,4]$. Therefore sustainable urban renewal (SUR) aims at improving the physical, social, economic and ecological aspects of abandoned urban areas through various actions, including redevelopment, rehabilitation, and renovation [5]. It is widely acknowledged that SUR cannot be successfully implemented through the promotion of piece-meal and isolated urban transformation projects or regulations [6]. Single-sector, and single-agency approaches to urbanizing China have experienced major limitations in dealing with social, economic, and environmental issues [7]. This regulatory fragmentation and broken linkages between the various considerations affecting SUR highlight the lack of an overall strategic approach [8]. Planning action 
and policy intervention at both city and regional level still remained local initiatives. Consequently, duplicated efforts as well as contradictory policies hamper urban development and result in stifled economic opportunities, higher public expense and exacerbated problems of public dereliction and community deprivation [9]. Contrariwise, a city and regional level strategic framework which could be conducive to an integrated policy can be expected to assist urban renewal projects by clearly defining environmental and social objectives, without compromising economic development in the long term $[10,11]$.

Chinese cities have grown rapidly with the urbanization rate in China increasing from $17.9 \%$ in 1978 to $57.35 \%$ in 2016 [12]. Along with this growth, urban planners are now facing the dilemma of how to accommodate ever increasing urban populations versus finite resources available for energy, space, and land [13]. SUR has been recognized as a viable solution to alleviate these emergent challenges. Government, from national level down to municipal level, have begun to pay attention to the need for urban renewal [14]. China's first regulation addressing the renewal of urban villages was issued in 2004 to deal with old industrial parks across China. Subsequently, a series of supporting regulations, measures, standards, and rules have been instituted. Many of these efforts have gained some desirable outcomes through the establishment of relevant authorities and regulations. Nevertheless, observers also noted that negative outcomes manifested in spatial segregation lead to gentrification, and ultimately increased social inequality [15-17]. Where previously, demolition and reconstruction were proved, as a fast-track means to increase economic benefits, and as an intervention in the form of urban renewal to restrict gains for fewer people [18]. Moreover, institutional barriers hindered the implementation process, particularly in ubran village redevelopment [19], while the demolition-redevelopment method promoted by the government not only threatened the livelihood of rural migrants, but also impacted on the local culture and the urban labor-intensive economy [20]. Simply, uncoordinated administrative powers may act to both assist as well as thwart SUR [21]. Evidently, the current model of Chinese urban renewal practices may not be sustainable, and providing a strategic approach to achieving SUR is thus needed [22]. On the one hand, citywide strategies on SUR remain limited. Current studies focus more on local market and social facilitation measures. They lack planning from the macro perspective and governmental level. On the other hand, those experiences of successful macro-level SUR strategies that do exist are from Western countries. The lessons drawn from these experiences have limited applicability in China, given China's institutional and social-economical characteristics, as well as its immature stage of policy development. Thus, institutions, administration efforts, and government behaviors are further important determinants in crafting a strategy suited to China [23].

Subjective perception is the manner in which an individual holds a view based on the workings of his own experiences. Such perceptions provide a basis, not intended to reveal universal truths, but to solve problems and offer perspectives for each individual or interested party according to their own judgments [24]. The perceptual state of engaged and informed subjects may lead to a better understanding of the actual processes unfolding with regard to urban renewal practices and project implementation [25]. This consideration provides an opportunity to test the influence of self-perceived, subjective attributes of government behavior on urban renewal. Assessing people's attitude, experience, as well as their knowledge on actual urban renewal projects, and to evaluate their overall expectation at making the right decisions, is a pressing concern in sustainability. Questions on attitudes are a proven powerful tool in explaining urban renewal performancs towards sustainability [26]. Therefore, a SWOT (strengths, weaknesses, opportunities, and threats) analysis also provides an important window to understanding self-perceived behaviors and expectations, as well as to identify various urban renewal practices [27].

However, traditional approaches to urban renewal decision-making generally neglect an individuals' subjective perception on project development. This study identifies the influence of people's subjective attitudes on stakeholders' actions. Firstly, it uncovers how decisions are made. Secondly, it clarifies the key problems and challenges in urban renewal. Finally, it illustrates how SUR 
in Chinese cities were understood. This study employs a SWOT analysis of people's perceptions on the impacts of urban renewal, along with its workable strategies for sustainability. Shenzhen, is examined as a case city in this study, addressing the consideration of SUR facilitation from the governments' perspective. This paper is organized as follows: research methodology in Section 2 followed by SWOT analysis in Section 3, summarization of development strategies and discussion lie in Section 4, and then concluding remarks in Section 5.

\section{Research Design}

\subsection{Study Area}

Shenzhen is located on the Pearl River Delta in Southern part of China (See Figure 1), and is one of the most international and innovative cities in China. In 1979, Shenzhen was a small fishing village with around 300,000 indigenous people. Due to its close vicinity to Hong Kong, Shenzhen was nominated as the most suitable region to experiment with an export-oriented economic model [20]. In order to attract external capital, management experience, and progressive skills, the Chinese central government designated Shenzhen as a Special Economic Zone (SEZ) in 1980, after which it became the first city to implement mechanisms of market economy without being directly controlled by the central government [28]. Since then, the city has grown at an incredible pace for more than 30 years, with its GDP (Gross Domestic Product) rising from RMB 200 million in 1979 to RMB 1.7 trillion in 2015, and the population increasing five hundred-folds, from 30 thousand people to 10.4 million people [29].

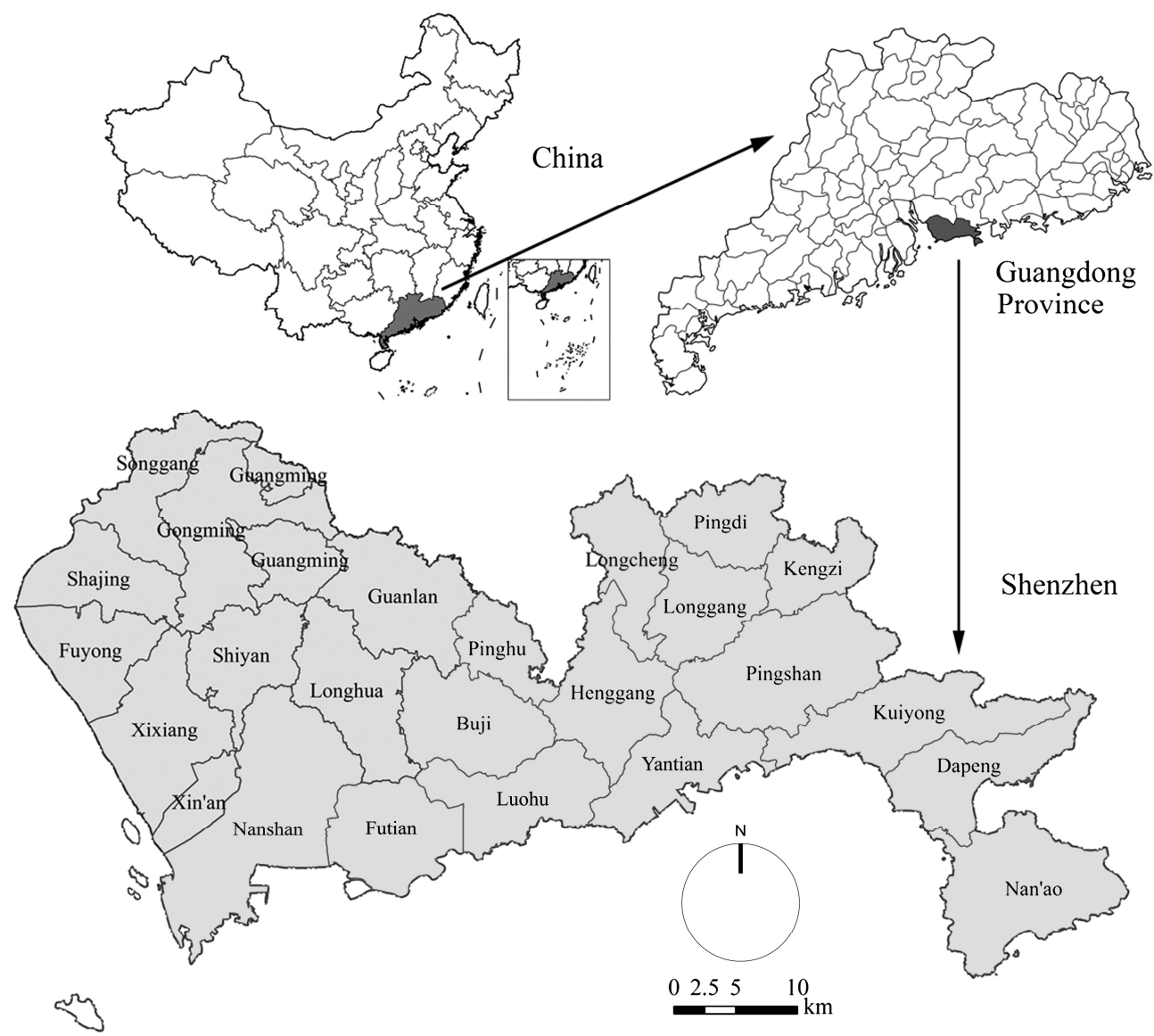

Figure 1. Geographic location of study; Shenzhen City, Guangdong Province, China (Sources: The authors). 
Urban renewal in Shenzhen has been a key component of urban development since 2000 [20]. This was mainly because Shenzhen has limited land resources and it has been difficult to meet the enormous demands for land use to sustain urban growth [30]. Thus, urban renewal has been regarded as one of the most important issues faced by the Shenzhen government. This challenge undoubtedly is more severe for Shenzhen compared to any other municipal governments in China. Accordingly, Shenzhen published specific rules referring to urban villages in 2004, and then actively promulgated urban renewal regulations in 2009. As of now, the urban renewal plan in Shenzhen has incorporated approximately 650 projects (See Figure 2). The land use supply through the development of urban renewal rose to around 2.5 million square meters in 2016, accounting for about 35 percent of the total land supply in Shenzhen [31]. However, only one-third of the total planned urban renewal projects were implemented successfully, and this less than expected result have signaled the need to rethink the existing approaches, and re-evaluate the current SUR strategies. Furthermore, there is no national level regulation or related planning strategy for urban renewal in Mainland China. Thus, most cities have come to recognize the importance and urgency of this matter. This study aims to provide a strategic analysis of Shenzhen's SUR. The lessons from Shenzhen's practices can offer meaningful implications for proposing and implementing urban renewal policies in other Chinese cities in the future.

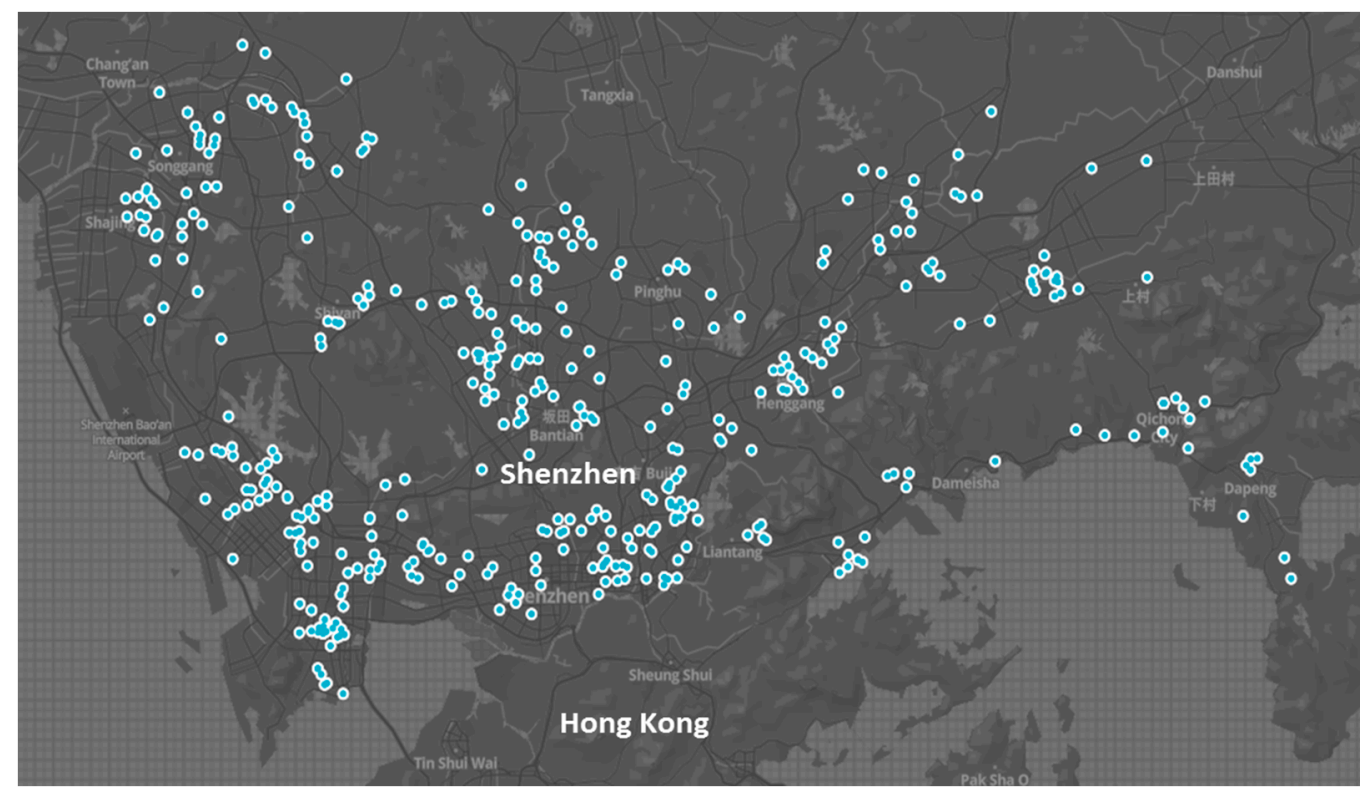

Figure 2. The overall layout of planned urban renewal projects in Shenzhen (Sources: The authors).

\subsection{Method and Research Framework}

\subsubsection{Method}

This study applies SWOT analysis to identify the strategies of SUR in Shenzhen. SWOT is a ubiquitous analytic instrument for helping planners leverage strengths, reduce weaknesses, realize new opportunities and avoid potential risk. This is done by listing internal and external issues in the four quadrants of the SWOT analysis grid [32]. SWOT analysis originates from the businesses management field, and due to its simplicity of operation and easy to understand technique, it has been employed in diverse disciplines [33]. For example, in the field of urban planning, SWOT analysis has been used to evaluate the effectiveness between urban management approaches and the procedural planning approaches [34]; an intelligent program management information system was developed to assist the decision making of urban renewal projects based on analysis of SWOT [35], while revitalization strategies was established in historic urban quarters [36]. These examples testify that the SWOT analysis technique is a viable approach for designing strategic thinking and procedures. 


\subsubsection{Research Framework}

This study was conducted in four steps. The first step examined the status quo of urban renewal practices in Shenzhen. Data consisted of two categories. The first category incorporated regulations, planning and programs of urban renewal, summary reports, and relevant literature from governmental and academic data. The second category comprised of data collected from interviews with staff of urban renewal authorities, developers engaged in urban renewal development, and local residents of urban renewal areas. The comparative analysis of the two categories provides valuable information on current challenges confronted by the Shenzhen government.

In the second step, four clusters of interview questions were formulated to examine the strengths, weaknesses, opportunities, and threats of implementing SUR.

Thirdly, a systematic SWOT analysis was conducted, in line with the designated research questions. Responses to these questions were explored and analyzed via telephone interviews with major related stakeholders, including an official from the Land and Resources Commission of Shenzhen municipality and an urban planner from the Urban Planning and Design Institute of Shenzhen. Both the respondents are responsible for urban renewal management at the district level. The telephone interviews were conducted in 2015, with each interview lasting for around 40 minutes. Focus group meetings were further conducted in 2016 with participants including an accounting manager from the Center for Assessment and Development of Real Estate, two managers from real estate companies, and community leaders from urban village collectives. Then, related stakeholders involved in various decision-making process of urban renewal were invited to discuss the strengths, weaknesses, opportunities, and threats encountered in the urban renewal process. The participants all have an in-depth understanding of the current urban renewal environment and practices. Although the viewpoints of inhabitants and tenants, particularly those living in urban villages or disadvantaged urban areas planned for urban renewal remain important, the major aim of this study is to explore suitable SUR strategies from a governmental perspective. Thus, data was not collected directly from individual inhabitants and tenants.

In the fourth step, strategies for improving SUR in Shenzhen, as identified in the previous steps, were presented via semi-structured interviews with participants including an officer from the Urban Renewal Bureau in a certain district, a manager from Shenzhen Property Developers Association for Urban Renewal, a manager from the Shenzhen Chamber of Commerce for Urban Renewal, and a main developer. A profile of interviewees from the different bodies is presented in Table 1. This was done by focusing on these three aspects, as recommended by Dealtry [37], (1) Eliminating weaknesses, (2) Exploiting opportunities, and (3) Mitigating the effect of threats.

Figure 3 illustrates the four step of the research framework.

Table 1. The detailed information of interviewees from different parties and urban renewal projects.

\begin{tabular}{ccc}
\hline Number & Position & Organization or Company or Projects \\
\hline 1 & An officer & Land and Resources Commission of Shenzhen municipality \\
2 & A urban planner & Urban Planning and Design Institute in Shenzhen \\
3 & An operation manager & Main Developer \\
4 & An investment manager & Main Developer \\
5 & A community leader & A Urban Village Corporation Limited \\
6 & An accounting manager & Center for Assessment and Development of Real Estate \\
7 & An officer & Urban Renewal Bureau in certain district, Shenzhen \\
8 & A manager & Shenzhen Property Developers Association for Urban Renewal \\
9 & A manager & Shenzhen Chamber of Commerce for Urban Renewal \\
10 & A marketing manager & Main Developer \\
\hline
\end{tabular}




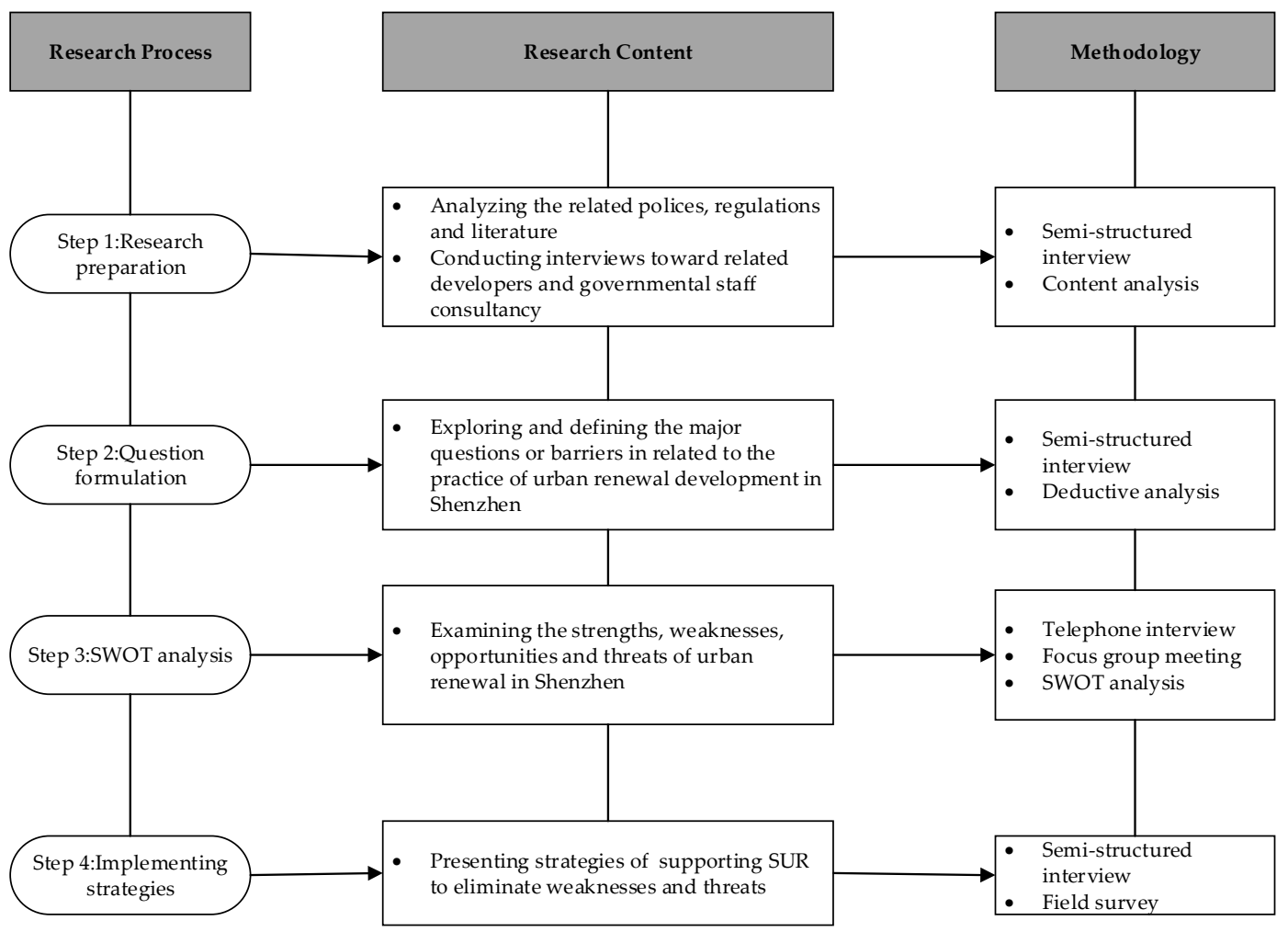

Figure 3. The four-step research framework (Sources: The authors).

\subsection{Formulations of Questions}

The research questions of this study are listed below:

- Question 1: What attributes does Shenzhen possess that would allow it to implement SUR? The first question aimed to identify the internal strengths for implementing urban renewal projects. During the group meeting, the question was phrased as follows:

- "What are specific advantages of promoting urban renewal development in Shenzhen?"

- "What factors enable Shenzhen to act as a pioneer city in implementing SUR?"

- Question 2: What limitations does Shenzhen have that inhibit adopting SUR? The second question aimed at examining the weaknesses encountered in the process of urban renewal projects. The question was phrased as follows:

- "What obstacles prevented Shenzhen from promoting SUR?"

- "What problems emerged in the SUR process in Shenzhen?"

- Question 3: What opportunities can Shenzhen exploit to stimulate SUR? The third question intended to identify future opportunities for SUR in Shenzhen. The question was phrased as follows:

- "What areas of SUR are there that Shenzhen can pursue?"

- "What possible approaches are there to encourage SUR?"

- Question 4: What threats does Shenzhen face that may impede SUR into the future? The last question aimed to identify the barriers that would limit SUR development in the long run. The question was phrased as follows:

- "What are the obstacles Shenzhen would encounter in stimulating SUR?"

- "What may make it harder for Shenzhen to adopt SUR in the future?" 


\section{Findings and Discussion}

Urban renewal in Shenzhen, as one of the instruments of the city's strategic development, is a critical and urgent issue owing to the unprecedented pace of population and industrial growth, exacerbated with an ever-shrinking pool of developmental land resources. SWOT analysis facilitated in identifying the internal and external conditions of the urban renewal challenge, and provided a theoretical framework for exploring further strategies for SUR. The results and findings of SWOT analysis over three rounds of discussions and interviews are summarized in Table 2.

Table 2. Results of SWOT (Strengths, Weaknesses, Opportunities, and Threats) analysis for SUR (Sustainable urban renewal) in Shenzhen.

\begin{tabular}{|c|c|c|}
\hline & Strengths & Weaknesses \\
\hline \multirow[t]{2}{*}{$\begin{array}{l}\text { Internal } \\
\text { conditions }\end{array}$} & $\begin{array}{l}\text { - } \quad \text { Geographically premium location } \\
\text { - } \quad \begin{array}{l}\text { Extensive experiences in urban } \\
\text { renewal governance and planning }\end{array} \\
\text { - A precursory city in enacting urban } \\
\text { renewal policies } \\
\text { - Current institutional innovations for } \\
\text { promoting urban renewal projects }\end{array}$ & $\begin{array}{l}\text { - Incomplete urban } \\
\text { renewal regulations } \\
\text { Lack of a comprehensive } \\
\text { decision-making process for } \\
\text { urban renewal } \\
\text { - Absence of governmental actions in } \\
\text { administrating urban renewal }\end{array}$ \\
\hline & Opportunities & Threats \\
\hline $\begin{array}{l}\text { External } \\
\text { conditions }\end{array}$ & $\begin{array}{l}\text { Prioritized treatment as a special } \\
\text { practice and experimental area } \\
\text { Empowered to allocate more spatial } \\
\text { resources for accomplishing the city's } \\
\text { development goal } \\
\text { - } \quad \begin{array}{l}\text { External support from the government } \\
\text { and industrial associations }\end{array}\end{array}$ & $\begin{array}{l}\text { - Unpredictable fluctuations of real } \\
\text { estate market } \\
\text { - Increasing pressure for urban } \\
\text { carrying capacity } \\
\text { - Insufficient funds for urban renewal } \\
\text { research and exploration }\end{array}$ \\
\hline
\end{tabular}

\subsection{Internal Conditions: Strengths}

\subsubsection{Geographically Premium Location}

Shenzhen is geographically close to Hong Kong and Taiwan, and strongly connected with them in terms of tourism and trade, as well as urban renewal experiences for sustainable development. In the 1980s, the Hong Kong government established the urban renewal authority (URA) to meet the pressing need for more urban space, and to promulgate a series of regulations to facilitate urban renewal projects [38]. Over the last two decades, the URA has adopted the " $4 \mathrm{R}$ strategies" to rejuvenate older urban areas by way of redevelopment, rehabilitation, and revitalization. With this strategy, URA has successfully implemented 59 redevelopment projects, 2727 rehabilitation projects, and 33 preservation projects, through to June 2016. In the same vein, before the 1980s, the Taipei government supported urban renewal with a dedicated financial budget and land appropriation law. From 2000, the financial burden forced Taiwan to turn towards promoting urban regeneration, and implementing urban renewal projects through the business model of public-private partnership (PPP) initiatives. Hitherto, Taipei has approved 266 urban renewal projects, with 103 completed and 67 in progress. These have increased cumulative property values to about TWD 1011.06 billion [39]. Clearly, both the Hong Kong and Taipei governments have gained significant success in effectively embracing SUR in their long-term planning operations.

When Shenzhen first turned to urban renewal from 2009, it clearly lagged behind Hong Kong and Taiwan. Government, institutions, and enterprises in Shenzhen lacked a full understanding or the necessary experience to prompt urban renewal projects. In one of the interviews conducted in this study, the officer in Urban Renewal Bureau admitted that the urban renewal institutions in Shenzhen 
observed and adopted the practices from SUR in Taipei and Hong Kong, rather than that of western countries. This was mainly because of the shared similarities between the three cities; specifically, patriarchal clan organization, community interrelationship, and common lifestyles. The interviewee presented that the geographical location of Shenzhen is an apparent strength compared with other cities in Mainland China. It is more convenient to enhance the extensive and perennial exchanges among these three cities in regards to experience of implementing SUR.

\subsubsection{Extensive Experience in Urban Renewal Governance and Planning}

In a short space of time, Shenzhen has transformed itself from an agriculture-based rural society into an industrial-based mega city [40]. This was largely achieved by encroaching on farmland. As a result, 320 urban villages were absorbed within the administrative area of the city by 2005 . The Shenzhen government viewed urban villages as a major problem consisting of extensive illegal construction, pervasive social issues, and poor quality urban space, all of which have to be solved [20]. From the beginning of construction of the main Luohu terminal train station, one of the oldest districts in Shenzhen, the city government started exploring large-scale urban renewal. At this time, it also introduced the Master Plan of Urban Village Redevelopment (2005-2010), along with two regulations for redevelopment of urban villages and old industrial parks. Additionally, from 2005 to 2008 annual developed plan was published, in which clearly identified the year by year redevelopment objectives and potential urban village redevelopment projects. However, by July 2009, despite tremendous efforts, only a small portion of the urban renewal projects within the Special Economic Zone (SEZ) of Shenzhen had been completed.

The implementation of the redevelopment program proceeded at a relative speed, and its progress lagged significantly behind the original planning schedule. The government responded with a series of edicts, including, for example, the Urban Renewal Rules of Shenzhen Municipality, enacted in 2009, which addressed many aspects of urban renewal, from planning, decision making, through to public engagement. Recently, the Shenzhen government has prioritized the implementation side of urban renewal by attempting to balance the involved stakeholder's interests while coordinating development across all over the urban districts, as a whole. In general, Shenzhen is the first city in China institutionalized and normalized procedures for the administration, regulation, implementation, and planning for urban renewal. One interviewee believed that urban renewal has entered into a new cooperative age, where the accumulated experience of government can play an important role in promoting development of SUR.

\subsubsection{A Precursory City in Enacting Urban Renewal Policies}

Since 2005, the Shenzhen government has issued a series of policies to encourage positive market effects and to improve procedural transparency. Compared to other Chinese cities, Shenzhen plays a leading role in regulations for stimulating urban renewal. Table 3 shows a summary of major regulations and policies for urban renewal in Shenzhen, along with their explanations. These regulations were separated into four levels: (1) Regulation, (2) Measure, (3) Technical specification; and (4) Guidance. As described previously, the starting date for establishing an umbrella urban renewal institution was 2009, when the Urban Renewal Regulations of Shenzhen Municipality was enacted. Soon afterwards, a series of followed-up urban renewal regulations and policies were formulated. These were designed to be normative as well as innovative, with incentives established to ensure and protect public expectations across urban renewal projects. 
Table 3. Regulations and policies for the urban renewal of Shenzhen.

\begin{tabular}{|c|c|c|}
\hline Item Level & Regulation or Policy & Main Effects \\
\hline \multirow{2}{*}{ Regulation level } & $\begin{array}{l}\text { Urban Renewal Regulations of Shenzhen } \\
\text { Municipality (2009) }\end{array}$ & \multirow{2}{*}{$\begin{array}{l}\text { These are the first regulations and } \\
\text { detailed rules that systematically } \\
\text { guided the development of urban } \\
\text { renewal in Shenzhen. }\end{array}$} \\
\hline & $\begin{array}{l}\text { Detailed Implementation Rules for Urban } \\
\text { Renewal (2012) }\end{array}$ & \\
\hline \multirow{5}{*}{ Measure level } & $\begin{array}{l}\text { Implementation suggestions of interim } \\
\text { provision for renewing “urban villages" (2005) }\end{array}$ & \multirow{5}{*}{$\begin{array}{l}\text { These policies in time sequence } \\
\text { represent the intention of } \\
\text { government. In 2005-2007, urban } \\
\text { villages' renewal and old } \\
\text { industrial park upgrading was the } \\
\text { main policy subjects. After 2009, } \\
\text { five interim measures were } \\
\text { enacted in 2010, 2011, 2012, 2014, } \\
\text { and } 2017 \text { respectively to response } \\
\text { to the existing problems and } \\
\text { overcome the bottlenecks to } \\
\text { promote urban renewal. }\end{array}$} \\
\hline & $\begin{array}{l}\text { Suggestions for regenerating and upgrading } \\
\text { industrial area (2007) }\end{array}$ & \\
\hline & $\begin{array}{l}\text { Suggestions for promoting further urban } \\
\text { renewal (2010) }\end{array}$ & \\
\hline & $\begin{array}{l}\text { Notice of specific action plan for accelerating } \\
\text { urban renewal (2011) }\end{array}$ & \\
\hline & $\begin{array}{l}\text { Interim measures for promoting the } \\
\text { implementation of urban renewal }(2012,2014 \\
\text { revised, } 2017 \text { revised) }\end{array}$ & \\
\hline \multirow{4}{*}{$\begin{array}{l}\text { Technical } \\
\text { specification level }\end{array}$} & $\begin{array}{l}\text { Technical provision for specific renewal plan's } \\
\text { compilation of urban village (2010) }\end{array}$ & \multirow{4}{*}{$\begin{array}{l}\text { These policies were standards and } \\
\text { provisions of administrative } \\
\text { documents for providing } \\
\text { low-income housing or innovative } \\
\text { industrial housing in urban } \\
\text { renewal projects. }\end{array}$} \\
\hline & $\begin{array}{l}\text { Technical provision for compilation of urban } \\
\text { renewal unit plan (2012 Trail) }\end{array}$ & \\
\hline & $\begin{array}{l}\text { Interim measures for providing low-income } \\
\text { housing in urban renewal project ( } 2012 \text { Trial) }\end{array}$ & \\
\hline & $\begin{array}{l}\text { Interim measures for providing innovative } \\
\text { industrial housing in urban renewal project } \\
\text { (2013 Trial) }\end{array}$ & \\
\hline \multirow{5}{*}{ Guidance level } & $\begin{array}{l}\text { Guidance for making schedule of urban } \\
\text { renewal unit planning in Shenzhen (2010 Trial) }\end{array}$ & \multirow{5}{*}{$\begin{array}{l}\text { These policies, guidance, and } \\
\text { operational rules were used to } \\
\text { regulate concrete procedure, } \\
\text { mainly addressing planning, } \\
\text { urban renewal unit approval, floor } \\
\text { area ratio examination, and old } \\
\text { industrial areas upgrading. }\end{array}$} \\
\hline & $\begin{array}{l}\text { Rules for approval of urban renewal unit } \\
\text { (2013 Trial) }\end{array}$ & \\
\hline & $\begin{array}{l}\text { Operational rules for land checking, building, } \\
\text { and managing the historical land ( } 2013 \text { Trial) }\end{array}$ & \\
\hline & $\begin{array}{l}\text { Technical guidance for examining floor area } \\
\text { ratio of urban renewal unit planning } \\
\text { (2015 Trial) }\end{array}$ & \\
\hline & $\begin{array}{l}\text { Operational guidance for upgrading } \\
\text { comprehensive renovation of old industrial } \\
\text { areas ( } 2015 \text { Trial) }\end{array}$ & \\
\hline
\end{tabular}

\subsubsection{Current Institutional Innovations for Promoting Urban Renewal Projects}

Despite the move to liberalized market in the Shenzhen Special Economic Zone since 1978, statutory planning regulations remained rigid in the rest of Chinese cities. Thus, those experiments of urban development that occurred in Shenzhen were viewed as institutional innovations. Indeed, Shenzhen consistently remains at the forefront of development compared to other metropolises in China [41]. Most interviewees from government and real estate firms agreed that the principal innovations were land-use right via agreements, urban planning systems, strict compliance requirements, and incentives. These innovative institutional practices in urban renewal project implementation differentiated Shenzhen from other Chinese cities.

Firstly, land-use right and land ownership are separated in Mainland China [42], with the municipal government leasing land use rights to developers for a fixed period of time, at a competitive 
price through auction, or tender, on the basis of Chinese national land law. However, during the process of making use of land in urban renewal projects for non-agriculture purposes, transferring land use rights between collectives or individuals and developers depends on reaching a successfully negotiated agreement [43]. Moreover, the government adopted a set of allocation standards for determining land-use fees and for distributing compensation. This fee was typically much lower than the real estate market value, since the price evaluation was an average price of commercial, residential, and industrial land, based on current conditions.

Secondly, with the city development mode transitioning from urban sprawl to inner city renewal, the original urban planning system was is difficult to adapt large scale renewal projects. Moreover, it needs to evolve from planning newly built-up areas to regulating inner city renewal neighborhoods [44]. Thus, the urban planning system for urban renewal was divided into two major components. One was the urban renewal planning component, established in 2009, which regulated implementation, defined the scope of urban renewal areas, issued planning standards in details, and formed the overall approval procedure for urban renewal projects. The other was the regional planning component, which consisted of the promulgated five-year renewal plan, along with the specific overall renewal plan. It primarily focuses on macro-level sustainable strategies and regional coordination.

Thirdly, the lack of public facilities is a common problem in urban renewal areas, especially under circumstances that profits are driven by real estate developers with limited land use areas in small-scale renewal projects. In order to maintain enough space for public facilities, Shenzhen set out rigid requirements that every urban renewal unit must provide a certain proportion of land for public facilities, amounting to not less than 3000 square meters, or more than $15 \%$ of the total demolished area. Meanwhile, the municipal government also enacted infrastructure planning standards in urban renewal projects and publicized the operational guidelines for controlling floor area ratios, to encourage property developers to build more public facilities, as well as affordable housing, and innovative industrial housing.

\subsection{Internal Conditions: Weaknesses}

\subsubsection{Incomplete Urban Renewal Regulations}

As already noted, Shenzhen has been playing a particular role in pioneering urban renewal regulations that were modeled across Mainland China. However, in comparison to developed countries, the existing regulatory system of urban renewal is immature, and needs further refinement. During the course of interviews, two of the most critical shortcomings of the current regulatory framework were identified, (1) the incompleteness of the current regulations, and (2) the difficulty of implementing existing practices.

The majority of interviewees believed that policies and systematic regulations could generate a stable basis for facilitating SUR. Nevertheless, there are difficulties in executing existing urban renewal regulations. Firstly, some policies may remain isolated within administrative offices and unpublicized, in the fear that these may somehow conflict with existing federal level legislation. Since the governmental officials are generally not from legal backgrounds, who worry about falling out of contradicting senior authorities. Secondly, interviewed government officials admitted that urban renewal regulations in Shenzhen focused too much on general principles, rather than dealing with specific practical issues. Thirdly, regulations related to SUR in Shenzhen was regarded as a new issue, under exploration, and thus incompatible with circumstances on the ground. These factors, collectively, exacerbated confusion in the execution of urban renewal policies.

\subsubsection{Lack of a Comprehensive Decision-Making Process for Urban Renewal}

Referring to market-oriented development of urban renewal model, these projects have their own specific decision-making process. Though the Shenzhen government has established decision-making process, there are two main concerns: Firstly, it lacks comprehensiveness, and secondly, the approval 
process is tedious. Moreover, there is no pre-assessment of social, economic or environmental conditions, prior to lodging an urban renewal project application. Similarly, post-evaluation of completed urban renewal projects do not occur. Compounding these deficiencies, there is lack of a mechanism for public involvement to take place during the decision-making process, and even tenants living in a targeted urban renewal area are excluded. Real estate developers pointed out that the approval process of an entire urban renewal project consists of about 25 sub-processes. In fact, the decision-makings processes are so tedious that it typically takes about three years to complete.

\subsubsection{Absence of Governmental Actions in Administrating Urban Renewal}

It is been a long while since the government dominated the urban renewal process, but the government nevertheless encounters many obstacles in developing urban renewal projects, especially those that are large-scale. With the implementation in Shenzhen of the many urban renewal regulations, enacted since 2009, a market-oriented urban renewal model has emerged. Real estate developers have become the dominant driving force, while government reverted to be an invigilator. Interviewed urban planners agreed that under the current market-oriented model, the "demolition and construction" development mode represented over $90 \%$ of all completed urban renewal projects. Even so, some areas most in need of development were completely neglected, and public benefit was never taken into account. The head of urban village collective made the observation that the urban renewal office was only an independent entity, and its frequently changing representatives, leading to ineffectiveness, higher costs, and overall uncertainty. By the same token, there was no standard to regulate transaction time, neither the qualification of developers active in the urban renewal market, nor a code of conduct by which they should operate.

\subsection{External Conditions: Opportunities}

\subsubsection{Prioritized Treatment as a Special Practice and Experimental Area}

Since liberalization of the market in 1978, Shenzhen, as China's first special economic zone, launched its innovative urban policy experiment. Based on the "Reform Development Planning of the Pearl River Delta region (2008-2020)," the strategies will attach more importance to perpetual reforms in the economy, society and environment. In addition, the annual plans of Shenzhen over 2010 to 2015, enacted concrete measures to accomplish short-term goals. Identifying strategies for genuine SUR over the near future has become a significant task for government. Interviewed government officials expressed the view that Shenzhen has established effective and innovative institutions for fostering development of SUR, including revised land-use right agreements, planning systems, standards, and incentives. Moreover, Shenzhen has enacted innovative regulations without the need for authorization and verification from the Chinese central government, which significantly shortens the overall time span and increases overall efficiency, while setting an example for other Chinese cities.

\subsubsection{Empowered to Allocate More Spatial Resources for Accomplishing the City's Development Goal}

According to "The 13th Five-Year Plan for National Economic and Social Development (2016-2020)," urban development focuses on two facets. One is to become a national, economic city and national industrial center for future-oriented industries. The other is to become an influential, international city in Asia, representing China, in global competition and cooperation.

In the current Shenzhen urban planning scenario, to 2020, the Ministry of Land and Resources will approve a total construction area of 976 square kilometers. Current vacant land is only about 43 square kilometers that accounts for just $2.3 \%$ of total (approximate 1952 square kilometers). The exploitation intensity of land resources is $49 \%$, much higher than international practice (the international benchmark for exploitation intensity at 30\%). Clearly, more space needs to accommodate new urban development in the near future. Although the development intensity is reach to a threshold, the land use efficiency (Gross domestic product per square kilometer) remains relatively low, at approximate RMB 976 million 
in 2016 comparing with Singapore (RMB 1966 million), and Hong Kong (RMB 1392 million). The officials from Shenzhen Urban Renewal Bureau believed that the strong demand for more urban space is a challenge, to which urban transformation through SUR could be a solution.

\subsubsection{External Support from the Government and Industrial Associations}

The Chinese central government highly valued the infill redevelopments for improving Shenzhen's land-use efficiency. For instance, in 2015, China's central city work conference on urban development, the 2nd time raised special attention from the central government after 37 years, for land use storage. Subsequently, the Ministry of Land and Resources enacted guidelines to promote redevelopment of inefficient land use. Urban renewal was at this point recognized as a crucial strategy across China. The interviewed government officials noted that the present SUR efforts had attracted strong interest from the Shenzhen government as well as related industrial associations. SUR has been viewed as an essential and significant urban strategy in the next few decades. The shortage of urban space represents the largest bottleneck in Shenzhen's development, which induced ten special action plans adopted in 2016, to improve the utilization of existing urban space.

In addition, industrial associations have also made great efforts to promote urban renewal. Various associations have started to focus on SUR; notably the Shenzhen Real Estate Association, and the Center for Assessment and Development of Real Estate in Shenzhen. At the same time, specific urban renewal associations were also established by many real estate developers, such as the Urban Renewal Developer Enterprise Associations and the Urban Renewal Chamber of Commerce in Shenzhen. These organizations hold the largest urban renewal summit forum every year, in which they aim to establish a communication platform for promoting business cooperation and institutional innovations. In this regard, the efforts of the Shenzhen government and industrial associations provide strong support for SUR.

\subsection{External Conditions: Threats}

\subsubsection{Unpredictable Fluctuations of Real Estate Market}

Unforeseen fluctuation in the real estate market is another major factor threatening SUR in Shenzhen. Housing prices reflect supply and demand levels, indicating the state of balance between receipts and payments in urban renewal projects. It reached a peak in 2016 , experienced with a $60 \%$ increase in prices (the average housing price reaches to RMB 53,454/square meter). Thus, Shenzhen has adopted strict measures to control the real estate bubble, with support from the central government, although overly severe controls may trigger market collapse. In the opinion of interviewed developers, it may not only decrease stakeholders' appetite for investing urban renewal projects, but also disrupt schedules of ongoing renewal projects, and harm the effectiveness of implementation since changing housing prices will bring difficulties of managing cash flow over the rebuilding period. Moreover, speculative fluctuations in the real estate market induce property owners to anticipate high property values, and consequently expect exorbitant rates of compensation in negotiating with developers during the demolition stage in an urban renewal project. Thus, wild fluctuation in the real estate market negatively burden on progressing urban renewal projects.

\subsubsection{Increasing Pressure for Urban Carrying Capacity}

The rapid urban development of Shenzhen has created strong pressures on the carrying capacity of the limited land and resources supply. According to the opinions of government officials and urban planners, the average population density of Shenzhen exceeded 9000 persons per square kilometer, reaching 30,000 persons per square kilometer in central district. Public service facilities and municipal infrastructure are unable to keep pace with the increasing demand. For instance, over the next five years, public schools need to accommodate about 40,000 additional students. Similarly, the total length of the planned Shenzhen sewer network is eight thousand kilometers, only $50 \%$ completed, and more 
than $35 \%$ of municipal pipeline in the Luohu and Futian districts, are aged and in need of replacing. Furthermore, only $50 \%$ of the planned municipal infrastructure, as tabled in The 12th Five-year Plan, were completed.

\subsubsection{Insufficient Funds for Urban Renewal Research and Exploration}

Interviewees acknowledged that relevant research is important to drive the practice of SUR, but research funding for urban renewal is extremely limited. Most funded research falls across four pillar industries, including technology, finance, logistics, and culture. Urban planners argued that planning theory and practice in China paid much attention to new urban area construction, but left incomplete urban renewal theory behind. Effective SUR in any future development needs financial support to carry out research for planning theory, legal systems, detailed standards, and effective decision-making methods, to name a few. Therefore, lack of research funding for urban renewal is also a significant obstacle to sustainable urban development in Shenzhen.

\section{Strategies for Promoting SUR}

Most of the research have focused on measuring sustainability of SUR [5]. There has been little done regarding implementing strategies of SUR, which emphasizes conceptual principals or related dimensions (society or environment), rather than operable strategies [3,45]. Based on the SWOT analysis results, a number of critical strategies for SUR were identified. These are shown in Figure 4. The basic principle of these strategies are to maximize strengths and opportunities, while transforming weaknesses into strengths, and mitigating threats. There are six clear strategies that addresses urban renewal issues in Shenzhen. These are S1-Promulgating related detailed urban renewal regulations; S2-Building a comprehensive and transparent urban renewal decision making information platform; S3-Forming various urban renewal partnerships that balance the role between government and market; S4-Encouraging multiple financial measures to facilitate implementation and reduce market risk; S5-Supporting the establishment of dedicated institutes for urban renewal research in Shenzhen, and S6-Publicizing SUR experiences via education and promotion. S3 was proposed to cope with W3 and T2, S4 was used to minimize the influence of W3 and T1, S5 was deployed to address W3 and T3, and $\mathrm{S} 6$ was set to minimize the influence of T3. The specific strategies are propounded in the following sections.

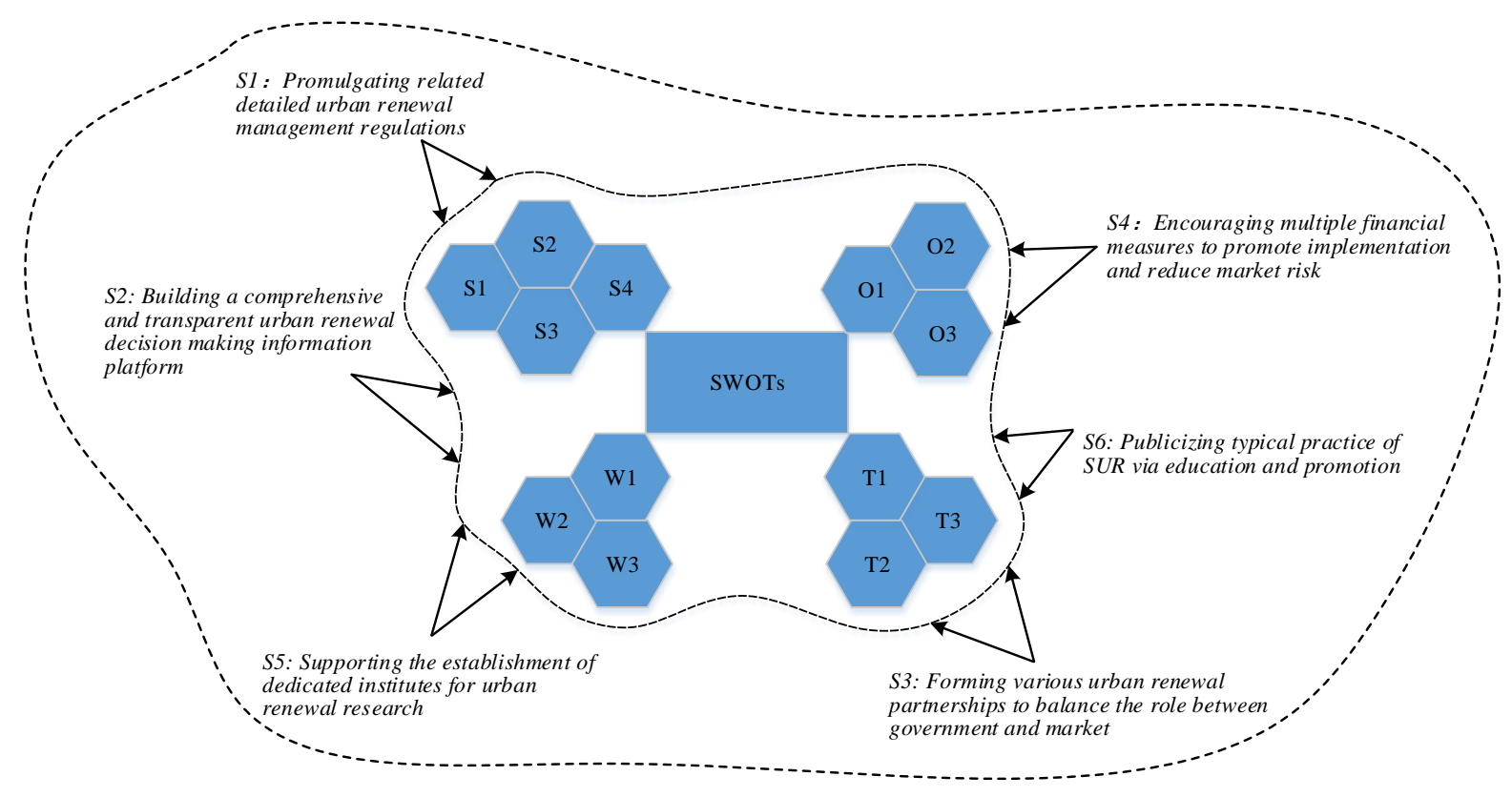

Figure 4. Emergent identified strategies for effective SUR (Sources: The authors). 


\subsection{S1: Promulgating Related Detailed Urban Renewal Regulations}

Regulations for SUR in Shenzhen are incomplete. Existing regulations serve primarily as an auxiliary administrative tool for monitoring urban renewal schedules, planning, demolition, and compensation. Interviews reveal that current regulations are too general to guide urban renewal projects effectively, and change frequently, adding to the uncertainty. Thus, regulations should be legitimized to cover a broader range of matters, including comprehensive impact surveys both before and after urban renewal projects, public involvement during decision-making process, and appropriate standards for organizations' entry qualification. For example, a set of urban renewal statutes should be enacted, with the Shenzhen government empowerment to ensure due implementation by developers and other stakeholders.

\subsection{S2: Building a Comprehensive and Transparent Urban Renewal Decision-Making Information Platform}

SUR is a complicated system which incorporates various components. It not only involves many specific decision-making processes in regards to schedule, confirmation of implementation, planning, and public involvement, but also involves different governmental departments with interests in land resources, urban planning, financial support, and facilities management, as well as jurisdictional responsibility over property developers, consultant enterprises, local inhabitants, and other non-governmental organizations. Besides, a large number of urban renewal projects have their own peculiar characteristics and implementation difficulties, which affect the general effectiveness of urban renewal. Therefore, an innovative and informative platform should be established in Shenzhen to facilitate a comprehensive decision-making process and effective transparent communication among parties to urban renewal projects (See Figure 5). The prototype of decision-making platform consists of four parts, including data storage service, urban renewal service (Backend), urban renewal service (Frontend) and urban renewal service website. Urban renewal service (Fronted), as the major parts of this platform, incorporates four modular (Schedule, Planning, Construction, and Ex-post evaluation of SUR) according to the typical process of urban renewal decision-making in Shenzhen. The potential ten service sections in Backend mainly is created to support the decision-making for urban renewal and all parties, such as citizens, inhabitants, developers, government, and experts, who are totally embodied in the informative flow of decision-making in urban renewal. 


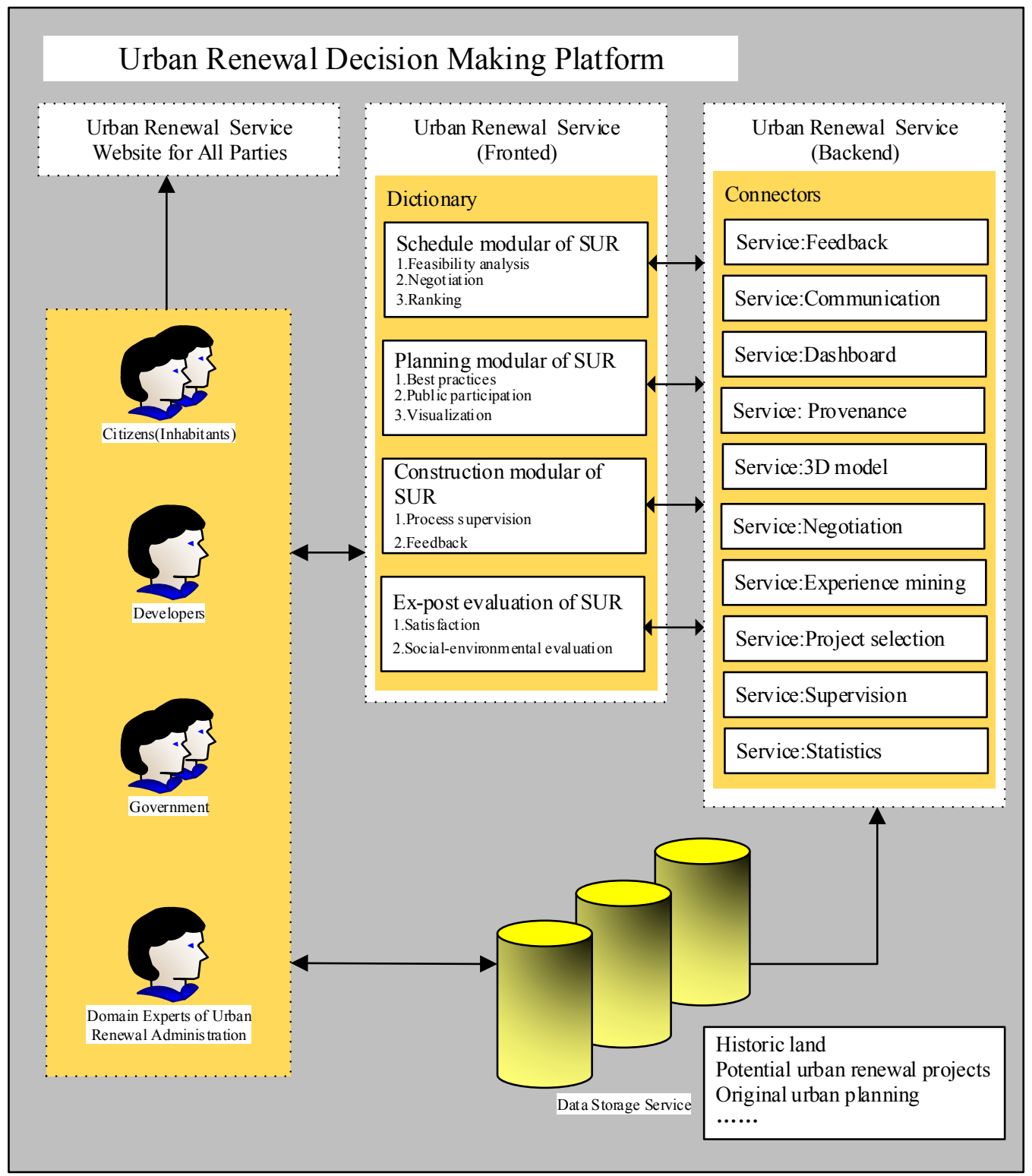

Figure 5. The prototype of urban renewal decision-making platform (Sources: [46]).

\subsection{S3: Forming Various Urban Renewal Partnerships to Balance the Role Between Government and Market}

Although there are three modes of urban renewal regulations (reconstruction, functional regeneration, and comprehensive renovation), noted above, the market prefers "reconstruction" as the dominant pattern. This approach does not favor the public benefit, and it comes with a high transaction cost. Therefore, a more balanced distribution of the three typical urban renewal patterns should be established. Firstly, major urban renewal projects need government intervention for implementation, participation, coordination, and supervision of specific decision-making processes; and for this a collaborative relationship should be constructed between government, market, and landlords. Secondly, the government should be responsible for demolition, land expropriation, and direct investment in urban renewal projects, which are of high public benefit but low market value, such as major infrastructure construction, historic preservation, environmental protection, and urban public safety projects. Thirdly, as for general urban renewal projects, government should take on the role of supporters and supervisors through the establishment of urban renewal regulations and workable schedules for urban renewal projects at macro level. 


\subsection{S4: Encouraging Multiple Financial Measures to Facilitate Implementation and Reduce Market Risk}

It is well known that the financial market of Shenzhen is one the best developed markets in China [47]. Private financing in Shenzhen accounts for one-third of total financial market volume. Existing financing methods of urban renewal projects currently rely on bank loans and local funding. The tedious approval process and unpredictable fluctuations of the real estate market can easily result in project stagnation. Thus, the multifaceted financial approach should be taken into actions. Considering the deteriorated community, public interests or urban renewal projects in remote areas, the government should establish public funds to facilitate these neglected projects actively. Applying these grants successfully to choose the targeted projects depends more on the competitive renewal scheme, feasible analysis and, meeting the planning requirements. Given deficiency of public financial methods at present and substantial private financial market of Shenzhen, on the other hand, the government should propose various financial methods to promote implementation of projects, while reducing market risk, such as REITs (Real Estate Investment Trust), corporate trusts, private equities, and corporate bonds. Besides, some innovative incentives also should be introduced for the implementation of SUR, including tax increment financing, public-private partnership, and land transfer rights.

\subsection{S5: Supporting the Establishment of Dedicated Institutes for Urban Renewal Research}

There is an emergent need for more specialized consultant corporations and non-governmental organizations in urban renewal, which can aid in bringing projects to market, optimizing collective stakeholder interests, and maximizing public benefits. In addition, relevant funds need to be set up support urban renewal research. Moreover, the government should support foundations for consultant corporations and non-governmental organizations through entry stimulation and market incentives. Meanwhile, a research center should be constructed to conduct SUR research. In the first stage, it can offer financial support to recruit researchers and staff. The institute can achieve a transition to self-funding by generating revenues through providing consultancy services for government and companies. This approach offers two advantages. Firstly, the organization may attract diverse parties in the process of urban renewal who want to establish an informal platform for mutual communications as well as to study urban renewal. Secondly, the organization can furnish high-quality consultancy service under the specific context of Shenzhen.

\subsection{S6: Publicizing Typical Practice of SUR Via Education and Promotion}

Clearly, urban renewal planning, regulation, and administration is complicated, and often changeable and unpredictable. Most practitioners are not familiar with the overall circumstances of urban renewal in Shenzhen. Therefore, it is suggested that government could improve training and education in this sphere, perhaps through non-government organizations: (1) to establish specific awards for the best practice in urban renewal projects; (2) to present the exemplar projects by launching a series of promotional activities via public relations and marketing campaigns; and (3) to provide sufficient training through seminars on urban renewal, and to involve interest participants, especially local communities. All of these can bring about a convergence of values and expectations, from all sides, regarding urban renewal.

\section{Conclusions}

The internal and external conditions of SUR in Shenzhen, China, were identified thorough SWOT. The results indicate that, in order to effectively facilitate SUR, Shenzhen city should undergo changes that leverage its advantageous. These are its geographical location and extensive experiences in urban renewal regulations and planning. Shenzhen has already played a leading role in promulgating regulations of SUR among many other Chinese cities. Moreover, Shenzhen has established certain institutional innovations for propelling urban renewal. Nevertheless, there are weaknesses, of which the major considerations are, incomplete regulations of SUR, lack of a comprehensive decision-making 
process, and the absence of effective governmental driven regulation and planning of urban renewal. The findings also provide an in-depth picture of some major opportunities that Shenzhen can utilize, as well as threats that it needs to address. The pressing imperative to acquire more spatial resource offers a strong external opportunity to meet the city's goal of urban renewal. Finally, external support from the government and industrial associations also form a concrete foundation for promoting SUR. However, threats to the success of SUR are also considerable, arising mainly from the unpredictable fluctuation in the real estate market, exacerbating pressures for urban carrying capacity, and insufficient funds for SUR research.

Based on the SWOT analysis, six critical strategies for improving SUR in Shenzhen were proposed. These strategies include: (1) Promulgating related detailed urban renewal regulations; (2) Building a comprehensive and transparent urban renewal decision-making information platform;

(3) Forming various urban renewal partnerships to balance the role between government and market;

(4) Encouraging multiple financial measures to facilitate implementation and reduce market risk;

(5) Supporting the establishment of dedicated institutes for urban renewal research in Shenzhen; and (6) Publicizing typical practice of SUR via education and promotion.

It is indicated that some actions involving these strategies started to come into effect in Shenzhen through efforts and attempts with SWOT analysis. SWOT is regarded as a tool in Shenzhen to efficiently provide supportive information for urban planning system and decision making. As consequences, many government agencies take advantage of SWOT to maximize governance effects and smooth decision-making progress, the necessary supporting information, which is essential to tune stakeholder's complicated opinions. SWOT analyses in Shenzhen practice for sustainable urban renewal could be improved referring to the strategies summarized in this study, which will also lead to strategic planning. Thus, we can draw conclusions that SWOT analysis gather much information for the achievement of sustainable urban renewal. Generally, SWOT analysis is not only strategically critical to Shenzhen's successful SUR, but also an effective method to analysis strategies of SUR in other cities. Moreover, the strengths, weaknesses, opportunities, and threats drawn from Shenzhen's urban renewal practices, which could be a current mentor city to others Chinese cities on urban renewal, provide a useful reference to improve SUR across China. The above-mentioned strategies are closely relevant to Chinese background situation, which local practitioners, decision-makers, and urban planning professionals can refer to in their future work.

Acknowledgments: This study was supported by the Program for New Century Excellent Talents in University (Grant number NCET-13-0635) and the National Social Science Foundation of China (Grant number 12AZD064), and Fundamental Research Funds for the Central Universities (Grant number CDJSK03PY01). The authors would like to thank Edwin H.W. CHAN from The Hong Kong Polytechnic University that provided certain help in the process of the survey. We also thank related authorities of urban renewal in Shenzhen, as well as the three real estate firms and other organizations discussed previously.

Author Contributions: Guiwen Liu and Wei Lang conceived and designed the experiments; Zhiyong YI performed the experiments and analyzed data. All co-authors drafted and revised the article together. All authors contributed to the writing of this paper and approved the final manuscript.

Conflicts of Interest: The authors declare no conflict of interest.

\section{References}

1. Couch, C. Urban Renewal: Theory and Practice; Macmillan: Basingstoke, UK, 1990.

2. Urban Renewal Regulations of Shenzhen Municipality. Available online: http://www.szpl.gov.cn/xxgk/ csgx/zcfg/201701/P020170119630731453239.pdf (accessed on 12 November 2016). (In Chinese)

3. Ng, M.K.; Cook, A.; Chui, E.W.T. The Road Not Travelled: A Sustainable Urban Regeneration Strategy for Hong Kong. Plan. Pract. Res. 2001, 16, 171-183. [CrossRef]

4. Bromley, R.D.F.; Tallon, A.R.; Thomas, C.J. City Centre Regeneration through Residential Development: Contributing to Sustainability. Urban. Stud. 2005, 42, 2407-2429. [CrossRef]

5. Zheng, H.W.; Shen, G.Q.; Wang, H. A review of recent studies on sustainable urban renewal. Habitat Int. 2014, 41, 272-279. [CrossRef] 
6. Roberts, P.; Benneworth, P. Pathways to the Future? An Initial Assessment of RDA Strategies and their Contribution to Integrated Regional Development. Local Econ. 2001, 16, 142-159. [CrossRef]

7. Chen, M.; Lu, D.; Zha, L. The comprehensive evaluation of China's urbanization and effects on resources and environment. J. Geogr. Sci. 2010, 20, 17-30. [CrossRef]

8. Richardson, L. A Review of "The Challenge of Social Innovation in Urban Revitalization, Paul Drewe, Juan-Luis Klein \& Edward Hulsbergen (eds) Amsterdam: Techne Press, 2008, ISBN 978-90-8594-018-0". Int. J. Hous. Policy 2009, 9, 357-359.

9. Turok, I.; Shutt, J. The challenge for urban policy. Local Econ. 2007, 9, 211-215. [CrossRef]

10. Healey, P. The institutional challenge for sustainable urban regeneration. Cities 1995, 12, 221-230. [CrossRef]

11. Silbergh, D. Management of Regeneration: Choices, Challenges and Dilemmas. Public Policy Adm. 2005, 20, 100-102. [CrossRef]

12. Tan, Y.; Xu, H.; Jiao, L.; Ochoa, J.J.; Shen, L. A study of best practices in promoting sustainable urbanization in China. J. Environ. Manag. 2017, 193, 8-18. [CrossRef] [PubMed]

13. Bai, X.; Chen, J.; Shi, P. Landscape urbanization and economic growth in China: Positive feedbacks and sustainability dilemmas. Environ. Sci. Technol. 2012, 46, 132-139. [CrossRef] [PubMed]

14. Zhou, T.; Zhou, Y.; Liu, G. Key variables for decision-making on urban renewal in China: A case study of Chongqing. Sustainability 2017, 9, 370. [CrossRef]

15. He, S. He State-sponsored Gentrification Under Market Transition The Case of Shanghai. Urban. Aff. Rev. 2007, 43, 171-198.

16. He, S. New-build gentrification in central Shanghai: Demographic changes and socioeconomic implications. Popul. Space Place 2010, 16, 345-361. [CrossRef]

17. Zhang, X.; Hu, J.; Skitmore, M.; Leung, B.Y. P. Inner-City Urban Redevelopment in China Metropolises and the Emergence of Gentrification: Case of Yuexiu, Guangzhou. J. Urban. Plan. Dev. 2014, 140, 5014004. [CrossRef]

18. Kochan, D. Placing the Urban Village: A Spatial Perspective on the Development Process of Urban Villages in Contemporary China. Int. J. Urban. Reg. Res. 2015, 39, 927-947. [CrossRef]

19. Lai, Y.; Tang, B. Institutional barriers to redevelopment of urban villages in China: A transaction cost perspective. Land Use Policy 2016, 58, 482-490. [CrossRef]

20. Hao, P.; Sliuzas, R.; Geertman, S. The development and redevelopment of urban villages in Shenzhen. Habitat Int. 2011, 35, 214-224. [CrossRef]

21. Hin, L.L.; Xin, L. Redevelopment of urban villages in Shenzhen, China-An analysis of power relations and urban coalitions. Habitat Int. 2011, 35, 426-434. [CrossRef]

22. Lin, Y.; De Meulder, B. A conceptual framework for the strategic urban project approach for the sustainable redevelopment of "villages in the city" in Guangzhou. Habitat Int. 2012, 36, 380-387. [CrossRef]

23. Tahal, R.; Chytková, Z.; Novinský, M. The Effect of Socioeconomic Classes on the Subjective Perception of Economic Situation. Stud. Commer. Bratisl. 2016, 9, 102-112. [CrossRef]

24. Gibson, J.J. The visual perception of objective motion and subjective movement. 1954. Psychol. Rev. 1994, 101, 318-323. [CrossRef] [PubMed]

25. Logothetis, N.K.; Schall, J.D. Neuronal correlates of subjective visual perception. Science 1989, 245, 761-763. [CrossRef] [PubMed]

26. Mohajeri, A.; Fallah, M. A carbon footprint-based closed-loop supply chain model under uncertainty with risk analysis: A case study. Transp. Res. Part. D Transp. Environ. 2016, 48, 425-450. [CrossRef]

27. Vonk, G.; Geertman, S.; Schot, P. A SWOT Analysis of Planning Support Systems. Environ. Plan. A 2007, 39, 1699-1714. [CrossRef]

28. Ng, M.K. City profile Shenzhen. Cities 2003, 20, 429-441. [CrossRef]

29. Shenzhen Statistics Bureau. Shenzhen Statistical Yearbook 2016; China Statistical Press: Beijing, China, 2017.

30. Tian, L. The chengzhongcun land market in China: Boon or bane?-A perspective on property rights. Int. J. Urban. Reg. Res. 2008, 32, 282-304. [CrossRef]

31. Liu, G.; Yi, Z.; Zhang, X.; Shrestha, A.; Martek, I.; Wei, L. An Evaluation of Urban Renewal Policies of Shenzhen, China. Sustainability 2017, 9, 1001. [CrossRef]

32. Helms, M. M.; Nixon, J. Exploring SWOT Analysis-Where are we now? J. Strateg. Manag. 2010, 3, $215-251$. [CrossRef] 
33. Hill, T.; Westbrook, R. SWOT analysis: It's time for a product recall. Long Range Plann. 1997, 30, 46-52. [CrossRef]

34. Halla, F. A SWOT analysis of strategic urban development planning: The case of Dar es Salaam city in Tanzania. Habitat Int. 2007, 31, 130-142. [CrossRef]

35. Kim, D.H.; Ahn, B.J.; Kim, J.H.; Kim, J.J. The Strategic Approach Using SWOT Analysis to Develop an Intelligent Program Management Information System (iPMIS) for Urban Renewal Projects. In 2009 Fourth International Conference on Computer Sciences and Convergence Information Technology; IEEE: Seoul, Korea, 2009; pp. 320-324.

36. Doratli, N.; Hoskara, S.O.; Fasli, M. An analytical methodology for revitalization strategies in historic urban quarters: A case study of the Walled City of Nicosia, North Cyprus. Cities 2004, 21, 329-348. [CrossRef]

37. Dealtry, T.R. "Dynamic SWOT Analysis": Developer's Guide; Intellectual Partnerships, Dynamic SWOT Associates: Birmingham, UK, 1992.

38. Adams, D.; Hastings, E.M. Urban renewal in Hong Kong: Transition from development corporation to renewal authority. Land Use Policy 2001, 18, 245-258. [CrossRef]

39. Driven Results of Urban Renewal in Taipei Urban Renewal Authority. Available online: http:/ / uro.gov. taipei /ct.asp?xItem $=316222094 \&$ CtNode $=12897 \& m p=118011$ (accessed on 13 July 2017).

40. Ng, M.K.; Tang, W. The Role of Planning in the Development of Shenzhen, China: Rhetoric and Realities. Eurasian Geogr. Econ. 2004, 190-211. [CrossRef]

41. Zacharias, J.; Tang, Y. Restructuring and repositioning Shenzhen, China's new mega city. Prog. Plan. 2010, 73, 209-249. [CrossRef]

42. Ding, C. Land policy reform in China: Assessment and prospects. Land Use Policy 2003, 20, 109-120. [CrossRef]

43. He, S.; Liu, Y.; Webster, C.; Wu, F. Property rights redistribution, entitlement failure and the impoverishment of landless farmers in China. Urb. Stud. 2009, 46, 1925-1949.

44. Chuanjiao, H.E.; Jiang, L.I. Study on Planning Standards for Urban Renewal Areas in Shenzhen. China City Plan. Rev. 2011, 20, 42-49.

45. Chan, E.; Lee, G.K. L. Critical factors for improving social sustainability of urban renewal projects. Soc. Indic. Res. 2008, 85, 243-256. [CrossRef]

46. Lopez, V.; Kotoulas, S.; Sbodio, M.L.; Stephenson, M.; Gkoulalas-Divanis, A.; Aonghusa, P.M. QuerioCity: A linked data platform for urban information management. In Lecture Notes in Computer Science (Including Subseries Lecture Notes in Artificial Intelligence and Lecture Notes in Bioinformatics); Springer: Berlin, Germany, 2012; Volume 7650, pp. 148-163.

47. Chen, H.; Wu, C. Forecasting volatility in Shanghai and Shenzhen markets based on multifractal analysis. Phys. A Stat. Mech. Appl. 2011, 390, 2926-2935. [CrossRef] 